\title{
Remixing the archive. The use of webdoc format as a medium for science communication
}

\author{
Guida Casella*
}

Resumo: O webdocumentário tem privilegiado a exploração de temas de relevância social mas, tem sido parcamente aplicado à comunicação de ciência. Este artigo argumenta que o formato do webdoc pode ser usado como meio para disseminar informação factual acerca de sítios arqueológicos. Descreve-se o processo de realização da narrativa interativa Histórias do Zambujal/Stories of Zambujal.

Palavras-chave: webdocumentário; narrativa; comunicação de ciência.

Resumen: El webdocumental ha privilegiado la exploración de temas de relevancia social, pero ha sido parcamente aplicado a la comunicación de la ciencia. En este artículo se argumenta que el formato del webdoc puede ser utilizado como un medio para difundir información objetiva acerca de sitios arqueológicos. En él se describe el proceso de realización de narración interactiva Histórias do Zambujal/Stories of Zambujal.

Palabras clave: webdocumental; narrativa; comunicación de la ciencia.

\begin{abstract}
Web documentary has been used to create awareness about social issues but it has been seldom used in science communication. In this paper I argue that the webdoc format can be used as a medium to disseminate factual knowledge about an archaeological site. We report the results of a practice-based research where archival material was remixed and structured into an interactive narrative entitled Histórias do Zambujal/Stories of Zambujal.
\end{abstract}

Keywords: webdocumentary; narrative; science communication.

Résumé: Le webdocumentaire a mis l'accent sur l'exploration des questions sociales, mais a été rarement appliquée à la communication de la science. Dans cet article on argument que le format webdoc peut être utilisé comme un moyen de diffuser des informations objectives sur les sites archéologiques. On décrit le processus de réalisation de la narrative interactive Histórias do Zambujal/Stories of Zambujal. Mots-clés: documentaire interactif ; narrative ; communication de la science.

* PhD Candidate in Digital Media, UT Austin Portugal Programm, Universidade Nova de Lisboa, Faculdade de Ciências Sociais e Humanas, Instituto de História Contemporânea - IHC. 1099-085, Lisboa. Portugal. E-mail: guidacasella@ gmail.com

Doc On-line, n. especial, dezembro de 2017, www.doc.ubi.pt, pp. 131-151. 


\section{Introduction}

Archaeology as a Science can be exciting. Through precise analysis of objective data in material remains of the past, archaeologists can understand the nature, typology, chronology and uses of places, constructing narratives around archaeological sites. These findings are usually published in academic volumes whose information contributes to augment scientific knowledge.

However, for the public who visits open-air archaeological sites, it is difficult to understand the value and meaning of a site unless some kind of "mediation" takes place. This mediation is usually part of an institutional "heritage interpretation plan" and can vary in genre and format, from an expert guided tours to information panels in situ to print or digital publications.

In the past years, many advances have been made in the development of digital applications for cultural heritage communication. From the beginning of Multimedia CD Roms to Virtual Museums, In-gallery or Mobile Applications and Games, these experiences are being used to enhance visitor's engagement in educational experiences.

Digital technology is not only fostering new forms of presentation of cultural content, but also changing people's perception and relation to Heritage. On the scientific community side there's an acknowledgement of the importance of public communication in order to maintain relevance and attract funding. On the public side there is an expectation to receive content about the world around them in their personal devices also in the context of cultural heritage visits.

The rich field for experimenting with digital media in archaeological communication reflects on a larger change in professional roles, increasingly adopting collaboration among professionals from different backgrounds (scientific and artistic).

This paper focus on projects where through an interactive cultural interface people can engage in a learning experience related to History and Heritage subjects.

First we start with the definition of interactive documentary and heritage interpretation, pointing to a common ground where digital creative and documental projects meet science communication.

Secondly we present five examples of interactive narratives that address cultural heritage communication discussing practical aspects of production, poetic approach and narrative structure.

Then we report on the planning and design process of Stories of Zambujal an iPad exhibition about a Copper Age Archaeological Site in Portugal.

We conclude with lessons learned and future work recommendations. 


\section{Background}

In this section we will explore (interactive) form and (factual) content in interactive documentary. We start by reviewing the definitions and characteristics of interactive narrative as a potential new art form. Then we move attention to 'content' in factual narratives, exploring the role of digital storytelling in archaeology.

\subsection{Form: Interactive Documentary}

Digital media was adopted in all kinds of human communication and production since the late $20^{\text {th }}$ century. Definitions of digital storytelling and interactive documentary point to the use of digital tools to tell stories (Lambert 2006) or to tell factual stories (Aston and Gaudenzi 2012) that are changing the ways we conceive narrative.

Interactivity, a characteristic allowed by digital media, is the possibility of creating hyperlinks within a digital document that act like a virtual button for a pre-scripted action to occur. In her book Computers as Theatre, Brenda Laurel (Laurel 1991) highlights the performative dimension of human computer interaction and points to changes in the conception of the artworks : "In many ways, the role of the graphic designer in human computer interaction is parallel to the role of the teatrical scene designer" (Laurel, 1993: 9). Interactivity also allows the creation of non-linear narratives fostering dynamic structures, and different readings, depending on the interactor choices.

Other characteristic of the digital medium is Multimediality, or the possibility of combining several types of media in one artefact (ex. text, image, video, sound). Multimedia allows adding sound and movement, an enrichment of content if compared to text and image characteristics of print culture.

Lev Manovich in his book The Language of New Media (Manovich 2001) identifies a number of key tools and processes introduced with digital media (eg. 'cut and paste', copy, find, delete, transform, etc. ) and compares them with traditional techniques of manipulating and editing film.

He considers the digital medium being in an experimental phase, just like collage and film was in the 1920s, and highlights the dominance of time based media in the ways we communicate today (through screens).

Connectivity through the Internet is also an important element of digital media. Artefacts that can be distributed worldwide in seconds. Nicola Negroponte, explores in "Being Digital" (Negroponte 1995) the ways Internet will change out lives, workplaces, institutions, commerce. He talks about "a change from atoms to bits". 
For Janet Murray (Murray 2013), digital media is characterized by the fact that computer programming underlies the human cultural experience with interfaces. But she proposes a humanist approach to digital artefacts, which she considers an art form as valuable as other cultural creations such as films, paintings or books. Janet Murray studied the impact of Digital Media in Narrative. In her seminal book Hamlet on the Holodeck: The Future of Narrative in Cyberspace she points 4 unique characteristics of Digital Media as being procedural, participatory, encyclopedic, and spatial.

The term 'interactive documentary' appears for its first time in 2002 in a text from Mitchell Whitelaw (Whitelaw 2002) for an exhibition catalogue of the artist Brogan Bunt for the Adelaide Fringe film festival in Australia.

In this text, Whitelaw links the connection between documentary and 'new media' to the independent production. With the simplification of software suddenly anyone could be a producer and filmmaker DIY. He also points out to new narrative formats and modes of perception "the viewer can wander around interactive narratives just like in other new media activities such as web surfing, database browsing and game playing" (Whitelaw, 2002:2).

Sandra Gaudenzi (Gaudenzi 2003) defines interactive documentary as the "use of Digital Media to convey factual stories". Arnau Gifreu Castells (Gifreu-Castells 2013) further elaborates and explores the characteristics of such creations as being "interactive, enabled by digital tools"; having "hyperlinks [that] allow the viewer to jump across different points of the narrative"; being Multimedia or "incorporating different types of media (image, text, video, audio, text, illustration, animation, infographics.)"; and presenting the "integration of graphic design: text, letters, interface, buttons".

This new genre that can be addressed with several terms: webdoc, interactive documentary, interactive digital narrative, virtual exhibit, database narrative, to name few. But we are still in an experimental phase. Like Manovich points out, when film was invented, movies didn't appear right away. There was a long evolution towards perfection, testing, changing, exploring the new medium. All media are new media sometime, before they stabilize and eventually become old (Gitelman 2006).

\subsection{Content: Narrative in Archaeology}

Let's move focus now to factual content, an element as interesting as interactivity. As Whitelaw states "true stories may be the crucial content that makes for a compelling new media experience" (Whitelaw 2002:1).

But what does it mean to document reality. And is there an objective way of representing it or are we always interpreting it in subjective ways? 
John Grierson (1898-1972) describes 'Documentary' as 'the creative treatment of actuality' (apud Nichols, 2007: 51) as a contrast with Dziga Vertov's vision of reality as it is.

In a similar way, in the field of scientific and heritage communication field, Freeman Tilden, a former worker at United States National Park Services, defined a strategy to transmit information to visitors, that inspired people working in mediation and education in the whole world. Based on his ' 6 principles of Heritage Interpretation', written in his notorious book 'Interpreting Our Heritage" Tilden defines effective storytelling as something more than the simple passing of factual information:

"Information, as such, is not Interpretation. Interpretation is revelation based upon information. But they are entirely different things. However all interpretation includes information. The chief aim of Interpretation is not instruction, but provocation" (Tilden 2007 [1957]: 18).

At the core of these propositions there is an evident dualism between objectivity and subjectivity in the way we communicate real facts.

It seems that the best way to understand this conflict is by acknowledging two different contexts of communication, inter-scientific (peers communication) and educational (popular communication).

Bienvenido Léon in his book The Narrative of Scientific Documentary (Léon, 2001) reflects on the problems of communicating science for the general public. Scientific knowledge differs form common knowledge precisely because it uses logic and objective mode, contrasting with common knowledge associated with emotional, subjective and sometimes irrational perceptions.

Léon identifies a clash between scientists and the media, where on one side, scientists mistrust media to transmit their knowledge, while the media is concerned in producing attractive texts and content in order to please the audience, appealing to emotions and often exaggerating and making use of sensacionalism. (León, 2001: 20). He states that for centuries, scientific knowledge was hold by an elite, and only recently, started to be of interest to the common citizens.

In a scientific field like archaeology, this conflict is even greater. The subject of archaeology is a public space or a monument, so the meanings attributed to this places are disputed between a scientific community, and the non-specialist, who, motivated by curiosity and interest want to claim some meaning for himself but maybe doesn't have the time or skills to research.

The interest in archaeology and heritage spaces doesn't seem to be slowing down. Maybe genuine, maybe a constructed input where $20^{\text {th }}$ century media have a role to play, in what Michael Shanks called archaeological imagination 
(Shanks 2012). From tv shows (Animal, Vegetable, Mineral; Time Team, etc.) to Hollywood movies (Indiana Jones, Troy, etc.) and more recently Video Games (Lara Croft, Assassin Creed, etc.) all media models how we relate to the past.

The contested zone between of what constitutes an archaeologist's perception of the subject and what the broad public can perceive depends on the "mediation" lens, or on the previous knowledge and tools to understand the space (Falk and Dierking 2016).

This tension results very often in too objective and "cold" public communication material which doesn't appeal or meet the needs and expectations of the lay audience, or the other way around, if there is too much subjectivity and speculation in reconstructions in ways that it doesn't seem scientific.

In a session entitled Archaeologists and Storytellers organized by Mary e Adrian Praetzellis in the Historical and Underwater Archaeology Conference in Atlanta in 1997, several authors discussed the role of narrative in communicating archaeology. The proceedings published in Historical Archaeology point three types of problems. First, subjectivity associated with narratives to construct the past can distort an objective view of what happened.

Secondly, the different settings of scientific communication and popular communication demand different professions: the scientist's role is to advance knowledge and present facts to his peers, while a science communicator or educator's role is to 'translate' complex realities to the lay audience. And these different contexts have implications in the forms of writing or presenting information in engaging ways.

Praetzellis sees the scientific approach of the archaeologists as an element of authority. He exemplifies that when an archaeologist writes an excavation report or presents the results in a scientific conference, he will be very carefull to stick to the facts he surveyed and interpreted. "Withouth this he would have no more authority than a simple man on the street."(Praetzellis, 1998: 1).

Thirdly he points out how telling stories about archaeological sites don't leave space to new interpretations. There is the idea that in presenting a clear image of what a site looked like in the past, instead of supplying information and access to knowledge, we are limiting and controlling a vision of a place or past event.

Yehuda Greenfield-Gilat critiques the effects of realistic digital media reconstructions in archaeological sites stating they can be "experienced as overly intensive and even intrusive" (Greenfield-Gilat 2008: 54) saying this kind of mediation promotes a "mythological reconstruction of reality" that ultimately separates the viewer from the subject. For him, a place should be left authentic 
in a way that the viewer can feel active and participant in the present that coexist with the remains of the past, even if some contextual information can be accessed in a complementary way (in a virtual museum online, for example) but avoiding a excessive "romantization" in situ.

This is why I would like to suggest in this argument, that the solution for a contemporary approach to heritage site mediation could be an approach through interactive documentary format. This way one can create an engaging way of presenting factual narratives without falling in speculation and "spectacularization" of archaeological sites.

Having set the field of interactive documentary and heritage interpretation. In the next section we will explore a few examples of interactive narratives that use cultural heritage content as topic.

\section{State of the Art}

To support and illustrate the use of interactive documentary in the context of cultural heritage communication, we present and briefly describe five different examples of interactive experiences selected from online observation. They represent a common topic (heritage communication) a common approach (interactive narrative), but were made in different dates (2006, 2009, 2012, 2014, 2016).

The discussion deals with practical issues like subject, narrative frameworks, user interface and overall experience, with the aim of explore practical aspects of production of this type of narratives.

\subsection{Atacama Stories ${ }^{1}$}

Is a cultural interface developed by Institute for Science Learning, University of North Carolina at Chapel Hill in 2006 to explore the cultural life of Atacama Desert, the driest place on earth. Content focus on human activities like mining, handcrafts and cultural traditions, and also in geology and astronomy (being the largest desert on earth it satisfies conditions for celestial viewing). The experience starts with an introduction that combines music and photo slideshow, after what we access a five chapters choice. Within each chapter we can explore subsections, profusely documented through text, image video and animation. The overall experience is very rich and the interface resembles early examples of multimedia CD Roms.

1. Atacama Stories (2006) http://atacamastories.jomc.unc.edu/ 

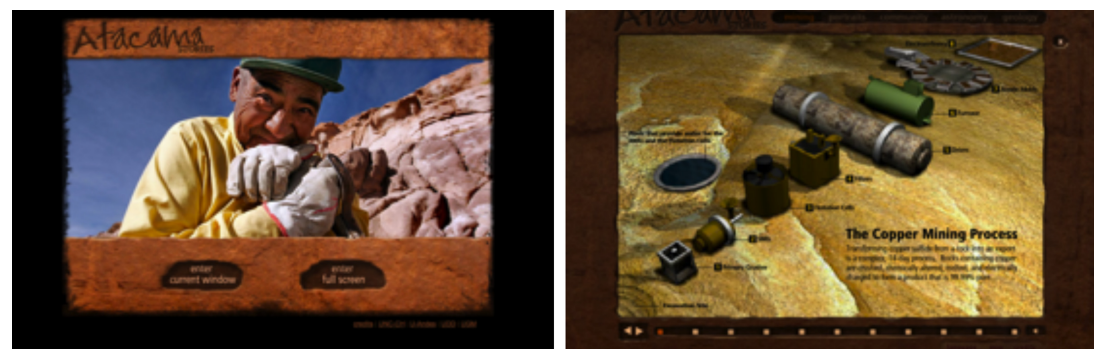

Figure1. Landing page of Atacama Stories, and interface showing interactive infographics

\subsection{Becoming Human ${ }^{2}$}

Is an interactive documentary that explores human evolution. The current version of the website was launched in February 2009 as the culmination of a project conducted by the Institute of Human Origins, represented by Jay Greene, and Rhino Internet Solutions. The narrative structure is divided in five chapters that combine short narrated videos and extra interactive features like an interactive timeline and a series of "exhibits" made with informative interactive content related to human evolution. The overall feel is engaging and exciting, partly due to the quality of content. It assumes itself as an interactive documentary.
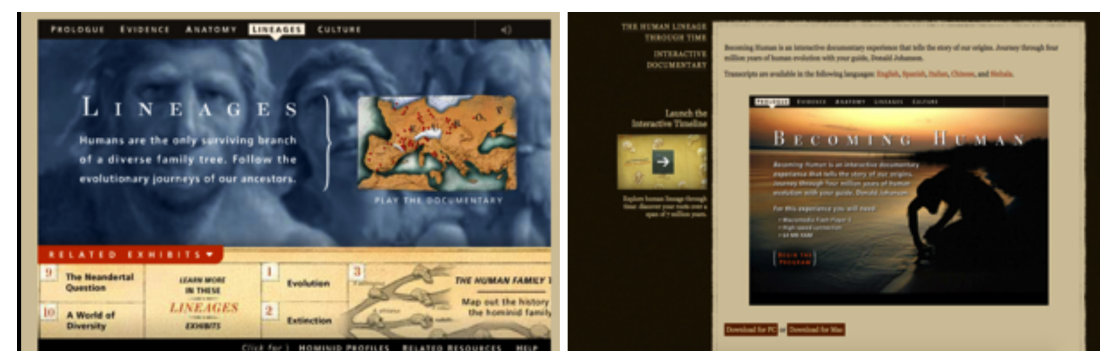

Figure 2. Landing page of Becoming Human interactive doc, and interface showing chapters, and interactive timeline

2. Becoming Human (2009) www.becominghuman.org/ 


\subsection{Matera Citá Narrata ${ }^{3}$}

A cultural interface that explores a city in Italy according to different perspectives. It was developed in 2009-2012 by the Italian Cultural Institut (Consiglio Nazionale delle Richerche). It is part of a transmedia strategy to explore a cultural territory, which combines the web site itself, a database, a game and walking tours in the city. The web site assumes several interactive documentary aspects, in the sense that it presents interviews, information, interactive maps and timelines to documents the city heritage through time and space. It also has a self-reflexive section with circa 90 interviews to the team of professionals that worked in the production of the website talking about what it means to make heritage interpretation, functioning almost as a meta documentary.
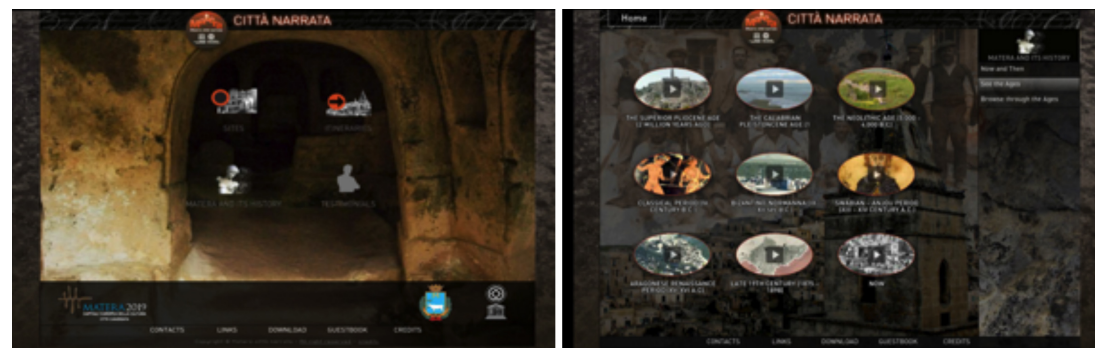

Figure 3. Interface of Matera Cittá Narrata showing the interface with video database

\subsection{A Global Guide to the WWI ${ }^{4}$}

Is an interactive narrative produced by The Guardian Online in 2014. Through a series of 7 chapters it presents the story of the WWI using film, text, audio and interactive infographics. In the beginning of each chapter there is a short video documentary of about 5 min (viewing time indicated graphically) and a button with a little hand links the viewer to additional information material. In this sections there are interactive maps and timelines, audio interviews, and archival material like newspaper articles, from that times. This is an example of how The Guardian is innovating online content, making use of interactive narrative.

3. Matera Citá Narrata (2012) www.itabc.cnr.it/progetti/matera-citta-narrata

4. A Global Guide to the WWI (2014) https://www.theguardian.com/world/ng-interacti ve/2014/jul/23/a-global-guide-to-the-first-world-war-interactive-documentary 


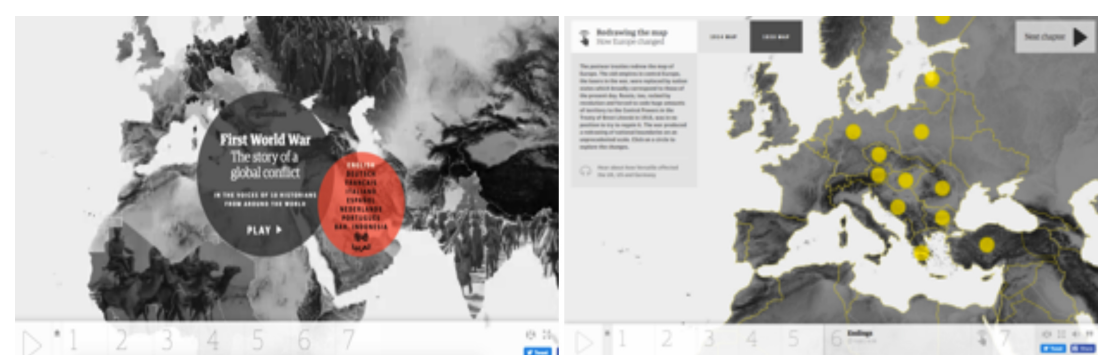

Figure 4. Interface of A Global Guide to the WWI showing the interface with the chapters menu in the bottom, and a page with an interactive map

\subsection{Magellan ${ }^{5}$}

Was produced in 2015 for arteTV.

In the project description we can read: "Experience the various facets of the first circumnavigation of the globe aboard Magellan's ship and discover the latest research on the subject in an interactive web documentary". The experience starts with a video that sets the viewer in the times of Magellan (16th century), and then presents a log book, the interface metaphor of the interactive experience. By clicking in one of the 6 chapters, we gain access to multimedia content including text, pictures and video that displays in full screen. The overall experience is very engaging in the use of a game-like mechanics.
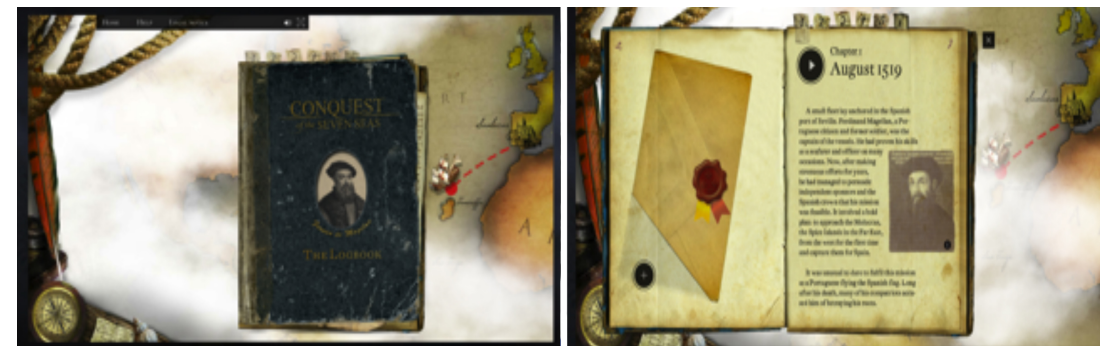

Figure 5. Magellan webdoc screenshot showing the interface metaphor as a book with six chapters, and the hotspots to access further content

These are only few of a vast number of examples of the use of interactive narrative to convey historical knowledge. These case studies exemplify several possibilities of combining different type of media (text, image graphics and

5. Magellan (2015) http://magellan.arte.tv/en 
video) in interactive interfaces with the shared topic of communicating factual narratives about cultural heritage referents.

In terms of narrative structure, they all have in common some basic features, like the introductory pages, the credit pages, a index in chapter menu (whose interface metaphor can vary more or less creatively) leading to several sections where the narrative unfolds.

Their interface and navigational architecture varies according to design choices and trends, and they can be more or less entertaining or immersive. The case of Matera Cittá Narrata although is the richest in content, doesn't allow a smooth "flow" experience, as for instance Magellan. The experience is marked by successive clicks to navigate content. Atacama Stories has the same situation of depending much on clicks contrasting with for instance The Global Guide to WWI, where the sound experience, or the animations provide a sense of unity among the several parts of the documentary. Although all experiences deliver culture - historical content, some seem to succeed more in engagement.

\section{How we made Stories of Zambujal app}

We now report the results of a practice-based research where archival material was remixed and structured into an interactive narrative called Stories of Zambujal.

\section{Research Setting}

Castro do Zambujal is a copper age site in Torres Vedras, Portugal, $50 \mathrm{Km}$ north east of Lisbon, near the Atlantic coast. It was discovered in 1932 by a local man called Leonel Trindade and have been systematically excavated and surveyed by the German Archaeological Institute since 1964. It is an important fortified settlement with 5.000 years, representing Bell Beaker culture known by being farmers, handcrafters of pottery, metal, wood, textiles and skeletal materials artefacts. They built a city like structure, maintained long distance commerce with the Mediterranean and Atlantic cultures. They didn't develop writing yet so all interpretation comes from material culture. This site is known worldwide because of its extension, quality of materials, and because it has original walls still preserved with 4 meters high.

In 2014 the 50 years of research from the German Archaeological Institute in Portugal were celebrated. On this occasion, the local Museum of Torres Vedras (Museu Municipal Leonel Trindade) developed a big documental exhibit. 
The planning and production of this exhibit provided an ideal research setting to develop what came to be Stories of Zambujal digital storytelling project.

With funding from my FCT Doctoral grant ${ }^{6}$ we've conducted a practicebased research project to make a prototype of a digital media artefact that fulfil the institution need to make available online some kind of virtual museography about Castro do Zambujal.

\begin{abstract}
Aim
The aim of this project was to build an interactive creative experience that would reflect the importance of telling stories about an archaeological site. More than remediating older media and narratives about this archaeological site, we wanted to create an autonomous piece that would stand by itself as an art form and could foster interest in the viewer to know more about archaeology in Torres Vedras.

The goal was to make an 'edutainment' piece, creative enough to be an experience in itself and rich enough to add a layer of meaning, that would complement, enrich, but not substitute, the physical exhibit or a visit to the open air archaeological site.

The style and language should be accessible both to experts in archaeology and the lay audience, but not exactly for school children or families. It should resemble more a long form journalism piece.

The key challenge was to make stories from the cultural heritage world more available to the local community using the Internet as a way to take the museum outside the walls and hopefully bring back visitors attention to the museum heritage and exhibits.
\end{abstract}

\title{
Process and Workflow
}

The prototype development process and workflow evolved as a sandbox project, in a very experimental mode, by doing first, testing and interacting afterwards.

We started by a visit to the archaeological site records archive in Madrid and in Torres Vedras, where we observed, discovered, digitized and classified different types of media. Using an ethnographic research approach we created

6. This research was funded by FCT - Fundação para a Ciência e a Tecnologia in the context of a PhD scholarship SFRH / BD / 51745 / 2011. PhD in Digital Media - Interactive Content Creation, UT Austin Portugal Program, Faculty of Social Sciences and Humanities, Nova University of Lisbon. 
categories and tags to the material, signing possible micro narratives. During this exploratory process we also collaborated with the team in developing the physical exhibit and several taglines and fun facts were identified.

After identifying specific narratives and media types to illustrate them, we did a rapid prototyping and sketching a first version of Stories of Zambujal. In this first iteration the user could browse a very simple interface divided in 4 sections: DISCOVERY section would display stories about the discovery of the archaeological site itself; SPACE would explore spatial narratives about the site through and interactive map interface; TIME would set the viewer in the specific archaeological time, using an interactive timeline; STORIES would be a mosaic of portraits with interviews to many players, highlighting multiple perspectives along the site, that inclusively would form a database that continued to grow. 


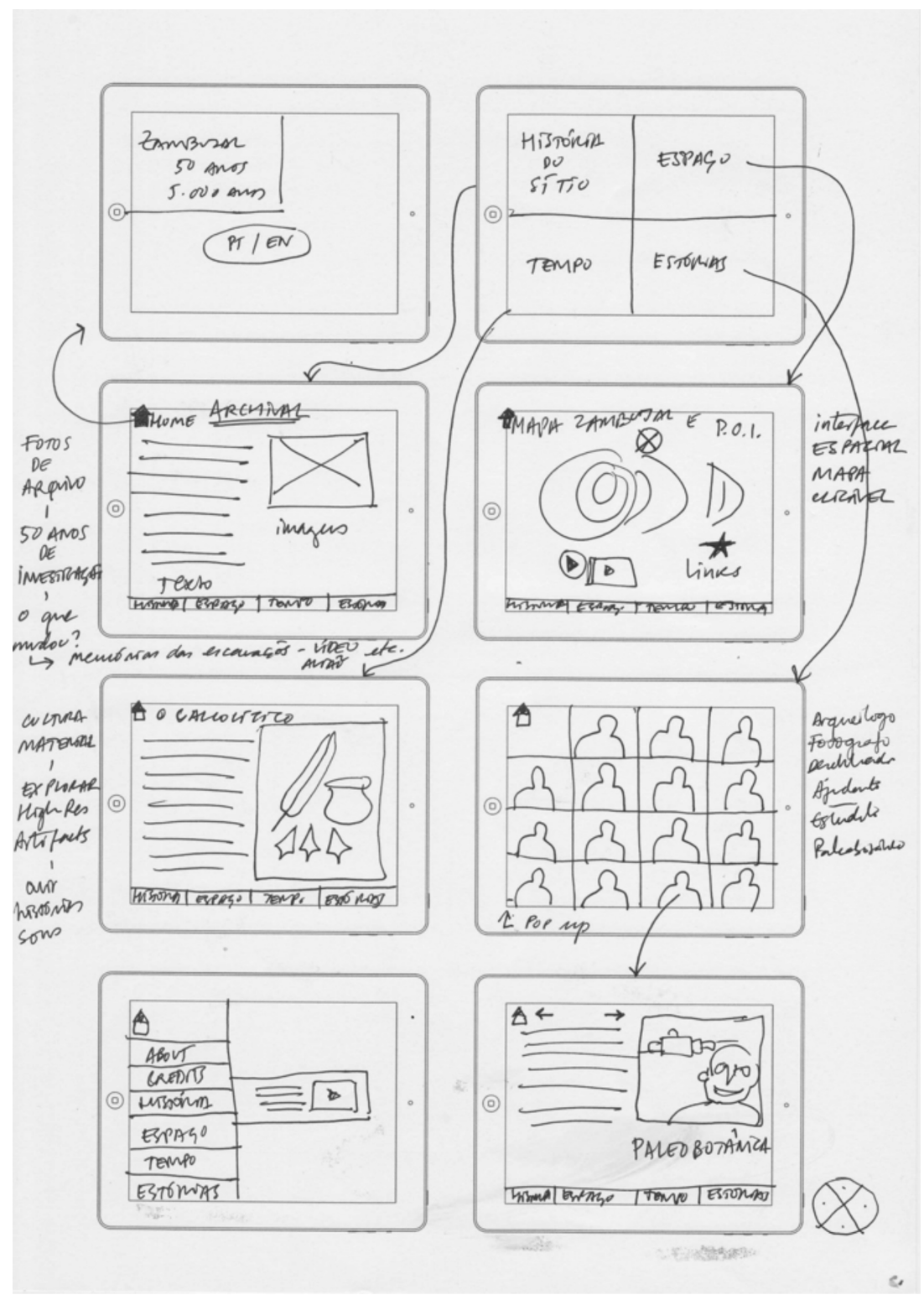

Figure 6. First sketch of Iteration 1 of Stories of Zambujal app

Nevertheless, this version felt like a simple database exploration without story or narrative. So when we had already collected more stories that emerged during our interaction with the team while engaging in the planning of the 
physical exhibit (launched in May 2016) we decided presenting a series of stories chronologically.

This became the final version that was developed further, towards an iPad prototype. In this actual version we have a landing page with an aerial view of the site, while hearing a sound bite in loop of the archaeologists tools working in the field - a sound like a hammer, scratching, voices and open air soundscape. Follows and introductory video of a creative remix or collage of different artefacts excavated.

We then are presented with a menu divided in 9 chapters.

Stories of Zambujal interactive narrative produces an historic mosaic that reflect on the scientific research campaigns and figures through time. It focus on assemble and interweave stories about the site (scientific, popular, folklore) in search of multivocality.
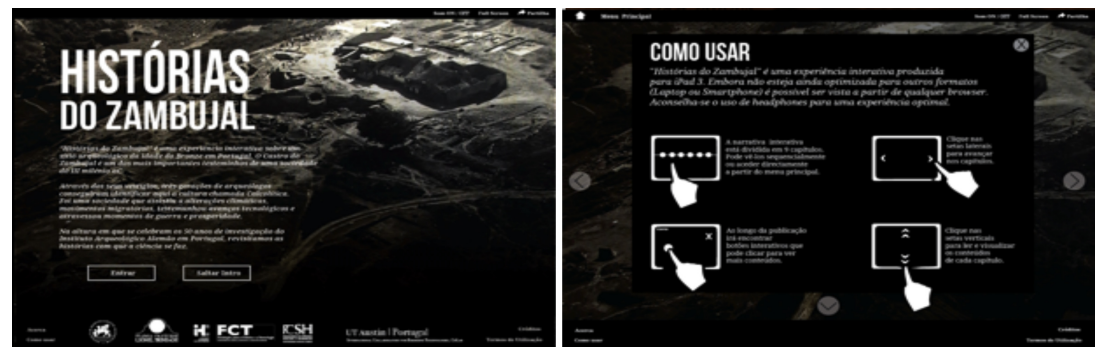

Figure 7. Landing page, instructions and credit page are essential elements
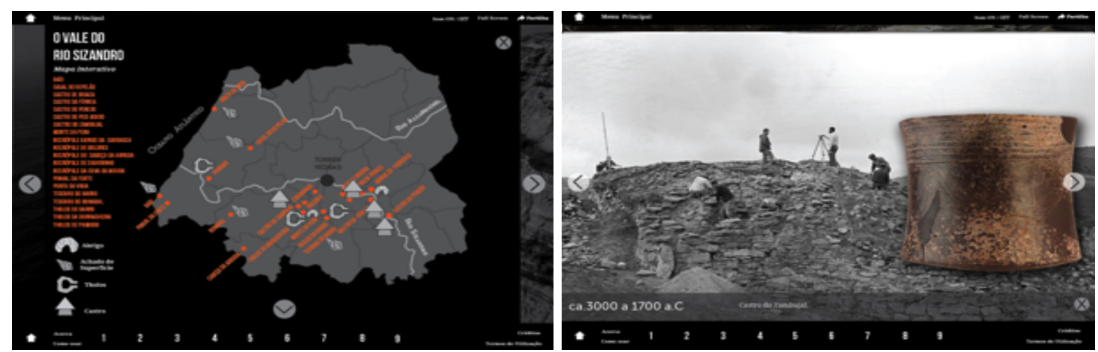

Figure 8. Interactive maps and timelines 


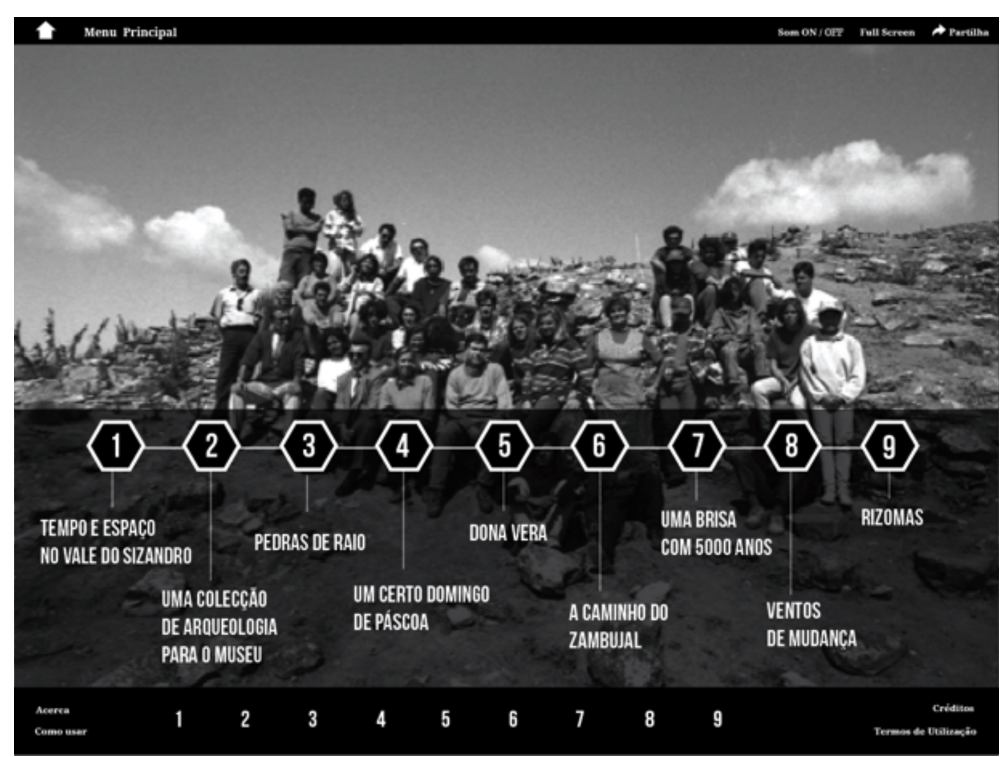

Figure 9. Main menu with the 9 chapters and flip bottom line to help navigation

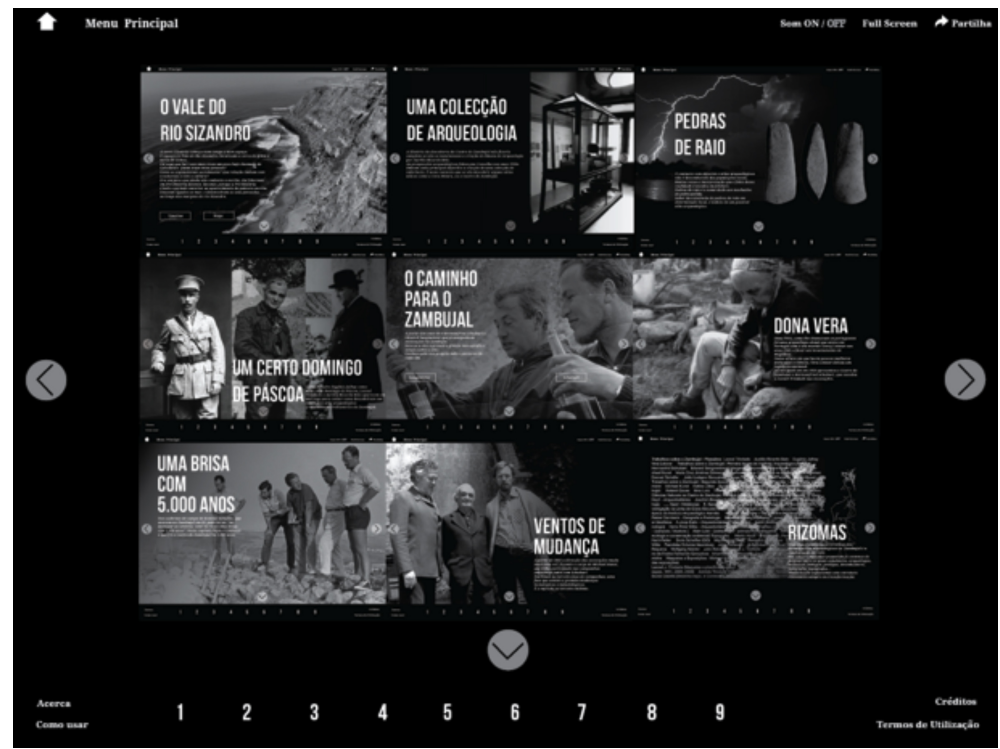

Figure 10. The 9 covers of the 9 stories 


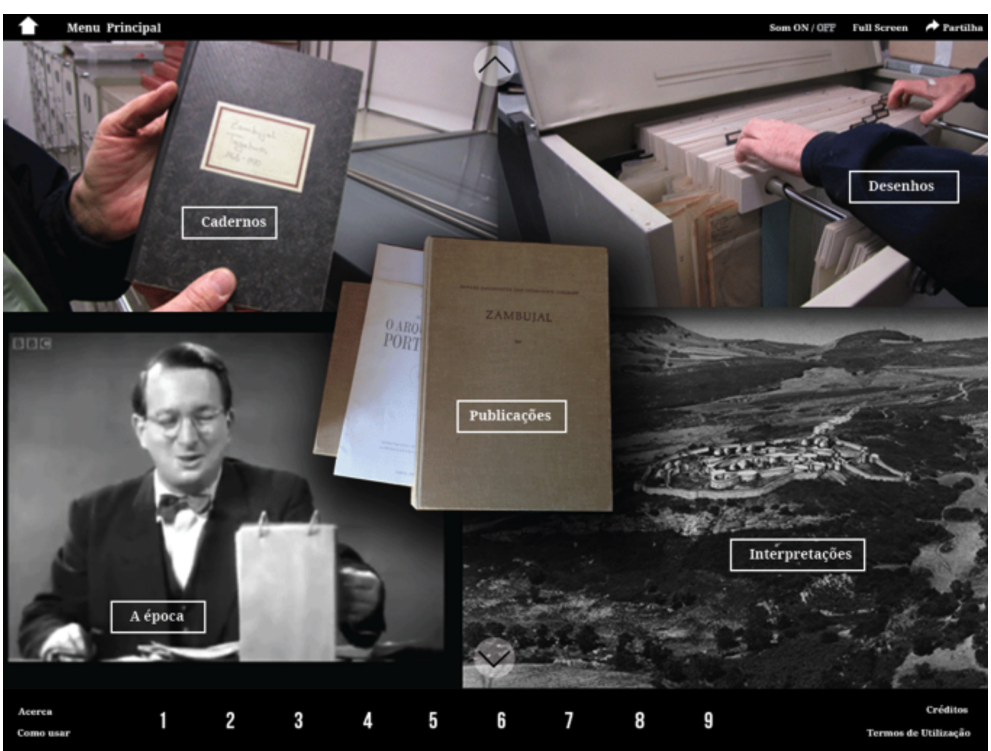

Figure 11. Integration of different types of media from the archive

\section{Limitations}

Even if we use a web app there is no 'one size fits all' approach. The app is optimized to an iPad 3, but we cannot control how viewers might access it, and all the alterations it can cause to the object. Even so, we opted to develop the experience for one ideal platform and test it for its intrinsic content, narrative structure, voice, and visual design and feel.

We conclude that the interactive narrative Stories of Zambujal presents itself both as a useful tool to make cultural heritage accessible to general audiences, and a challenging way to make memorization on archaeological sites, being the main challenge how to make content meaningful and relevant to general audiences yet retaining scientific depth and rigor.

Our hypothesis was confirmed that by adopting an interactive documentary framework and structure, and making use of digital storytelling principles, we met the requirements of providing both an accurate factual information and emotional storytelling about our subject. 


\section{Future Work}

Future work is needed in usability testing of the prototype. We need to test it in several dimensions. Test for Narrative Design (to find out its ease of use, effectiveness of interface design, appropriate gesture features, and also test for usability, checking for dead ends and coherence of assets navigation); Test for Content (check for a right balance between education and entertainment, assess if content is appealing and accurate enough for experts while bein enjoyable and accessible for lay audience); Test for Modes of Consumption (understand when will users access the app, if after or before the physical exhibit visit, or none. See if the app is effective in attracting new visitors to the museum); Test for the Teamwork (did the content responsible find it interesting? Where the experts keen to break walls and be more creative? Did the educators accept well the more objective specific information we included?).

\section{Lessons learned}

Multidisciplinary teams allow the interweaving of perceptions towards the project. A balance between a more objective and deep contextual information from the specialists, and the engaging creative perspectives of the designers, was achieved. We worked together for knowledge exchange combining factual authoritative info with more provoking / creative solutions.

The use of low budget technologies allowed a "do it yourself" approach. We used "Tumult Hype" program to produce the prototype of a Web App minimizing the need to hire programmers.

We also learned that there is no "one size fits all" approach to our prototype. We designed a piece aiming at an informed target audience, excluding children target group.

Finnaly, we learned that Museums are natural storytellers, they have objects and stories. But these stories need to be crafted with some sort of mediation and digital media can become these learning space.

\section{Conclusion}

In the project Stories of Zambujal we used our narrative and new media skills to create an interactive story based on a creative approach to the archive of Castro do Zambujal archaeological site.

Because we used digital media tools and creatively addressed factual material, we strongly believe our prototype can fall in the category of interactive documentary. 
By focusing on telling stories about the archaeologists and the story of the institution help us avoid romanticized interpretations of an archaeological site.

Assembling interviews and different stories about the excavation organizing them by episodes in the manner of interactive documentaries, gives an overall view of the different social actors that relate to the archaeological site, promoting multivocality and plural perspectives about the subject. This approach is aligned with other projects related to the connection of people with places, identity and memory.

With Stories of Zambujal app we have successfully helped the institution to share their less known stories in a good balance between fun facts and deeper explanations of the subject.

Last but not the least, our experience of manipulating an archive as a way of understanding a subject, pointed to a field that needs further theoretical investigation, that of curatorial approaches to archives.

\section{Bibliographic references}

Aston, J. \& Gaudenzi, S. (2012). Interactive documentary: setting the field. Studies in Documentary Film, 6 (2): 125-139. UK.

Arthur, P. L. (2008). Participating in the past: recording lives in digital environments. Cultural Studies Review, 14 (1), Mar. Available from: file:///Users /Mac/Downloads/2114-8559-1-PB.pdf. Accessed November 2016.

Baigrie, B. S. (1996). Picturing knowledge: historical and philosophical problems concerning the use of art in science. Toronto: University of Toronto Press.

Bateman, J. (2000). Immediate realities: an anthropology of computer visualisation in archaeology. Internet Archaeology, 8. Available from: http://intarch.ac.uk/journal/issue8/bateman_index.html. Accessed November 2016.

Deetz, J. (1998). Archaeologists as storytellers. Historical Archaeology, 32 (1): $94-96$.

Falk, J. H. \& Dierking, L. D. (2016). The museum experience. New York: Routledge.

Gaudenzi, S. (2013). The living documentary: from representing reality to co-creating reality in digital interactive documentary. Doctoral thesis, Goldsmiths, University of London. Available from: http://eprints.gold.ac. uk/7997/. Accessed November 2016. 
Gifreu-Castells, A. (2013). El documental interactiu com a nou gènere audiovisual. Estudi de l'aparició del nou gènere, aproximació a la seva definició $i$ proposta de taxonomia $i$ d'un model d'anàlisi a efectes d'avaluació, disseny i producció [The interactive documentary as a new audiovisual genre. Study of the emergence of the new genre, approach to its definition and taxonomy proposal and a model of analysis for the purposes of evaluation, design and production. Barcelona: Tese de Doctorado, Universitat Pompeu Fabra. Departament de Comunicació.

Greenfield-Gilat, Y. (2008). Through form and content. New media components and cultural heritage sites management, in the jewish traditional society. In Y. E. Kalay New heritage. New media and cultural heritage (pp. 53-77). London and New York: Routledge.

Gitelman, L. (2006). Always already new: media, history and the data of culture. Massachusetts: MIT Press.

Grierson, J. \& Hardy, F. (ed.) (1966). Grierson on documentary. Berkeley: University of California Press.

Lambert, J. (2006). Digital storytelling: capturing lives, creating community. New York: Digital Diner Press.

Laurel, B. (1991). Computers as theatre. Boston: Addison-Wesley.

León, B. (2001). O documentário de divulgação cientifica. Avanca: Cineclube de Avanca.

Manovich, L. (2001). The language of new media. Cambridge: MIT Press.

Murray, J. H. (1998). Hamlet on the Holodeck: the future of narrative in cyberspace. Cambridge, Mass: MIT Press.

Murray, J. H. (2012). Inventing the medium: principles of interaction design as a cultural practice. Cambridge: MIT Press.

Negroponte, N. (1995). Being digital. London: Vintage Books.

Nichols, B. (2007). Introdução ao documentário, $2^{\mathrm{a}}$ Ed. Coleção Campo Imagético, Campinas, São Paulo: Papirus.

Plantinga, C. (1997). Rethoric and representation in nonfiction film. Cambridge: Cambridge University Press.

Praetzellis, A. (1998). Why every archaeologist should tell stories once in a while. Historical Archaeology, 32 (1): 1-3.

Proctor, N. (ed.) (2011). Mobile apps for museums, the AAM guide to planning and strategy. Washington DC: American Association of Museums. 
Shanks, M. (2012). The archaeological imagination. Walnut Creek, Calif: Left Coast Press.

Tilden, F. (2007). Interpreting our heritage. Chapel Hill: University of North Carolina Press.

Whitelaw, M. (2002). Playing games with reality: only fish shall visit and interactive documentary. Available from: http://creative.canberra.edu.au/mit chell/papers/PlayingGames.pdf. Accessed November 2016.

\section{Webdocs}

Atacama Stories (2006), http://atacamastories.jomc.unc.edu/enter_eng.html

Becoming Human (2009), www.becominghuman.org/

Matera Citá Narrata (2009-12), www.materacittanarrata.it/

Magellan (2015), http://magellan.arte.tv/en

A Global Guide to the WWI (2014), www.theguardian.com/world/ng-interacti ve/2014/jul/23/a-global-guide-to-the-first-world-war-interactive-docume ntary 